\title{
Title:
}

\section{Gastrointestinal lymphoma, a rare endoscopic lesion}

\section{Authors:}

Irene Latras Cortés, María José Fernández Gundín, Sandra Diez Ruiz, Sandra Borrego Rivas, Luis Manuel Vaquero Ayala, Rubén Díez Rodríguez, Marcos Jiménez Palacios, Francisco Jorquera Plaza

DOI: $10.17235 /$ reed.2022.8555/2021

Link: PubMed (Epub ahead of print)

Please cite this article as:

Latras Cortés Irene, Fernández Gundín María José, Diez Ruiz Sandra, Borrego Rivas Sandra, Vaquero Ayala Luis Manuel, Díez Rodríguez Rubén, Jiménez Palacios Marcos, Jorquera Plaza Francisco. Gastrointestinal lymphoma, a rare endoscopic lesion. Rev Esp Enferm Dig 2022. doi: 10.17235/reed.2022.8555/2021.

This is a PDF file of an unedited manuscript that has been accepted for publication. As a service to our customers we are providing this early version of the manuscript. The manuscript will undergo copyediting, typesetting, and review of the resulting proof before it is published in its final form. Please note that during the production process errors may be discovered which could affect the content, and all legal disclaimers that apply to the journal pertain. 


\section{Gastrointestinal lymphoma, a rare endoscopic lesion}

Irene Latras Cortés, María José Fernández Gundín, Sandra Diez Ruiz, Sandra Borrego Rivas, Luis Manuel Vaquero Ayala, Rubén Díez Rodríguez, Marcos Jiménez Palacios, Francisco Jorquera Plaza.

Servicio de Aparato Digestivo. Complejo Asistencial Universitario de León (León)

\section{Corresponding author:}

Irene Latras Cortés

Servicio de Aparato Digestivo. Complejo Asistencial Universitario de León

C/ Altos de Nava, S/N. 24071 León

irenelatrascortes@gmail.com

KEYWORDS: Anemia. Colonoscopy. Lymphoma.

To the Editor:

We present the case of a 77-year-old male patient with iron deficiency anemia. His personal medical history is: dyslipidemia, high-grade diffuse centrofollicular lymphoma localized in the tonsil in 1984 and metastatic prostate cancer treated with hormone therapy.

In order to investigate iron deficiency, we performed a colonoscopy. The bowel preparation was inadequate, so it was difficult to visualize the colonic mucosa properly. However, an angiodysplasia was located in what seemed to be the cecum, and we performed argon plasma coagulation with no immediate complications.

A month later, the patient was admitted to Hospital because he had presented abdominal pain located in right iliac region since the procedure, RCP level of $20.5 \mathrm{mg} / \mathrm{l}$ and ultrasound findings of inflammatory/tumoral process in cecum.

A CT scan was requested, which was suggestive of primary lymphoma in terminal ileum. Another colonoscopy was performed, and we identified an infiltrative lesion next to appendix that was biopsied (Figure 1). The pathology report revealed infiltration by diffuse large B-cell lymphoma (DLBCL) with follicle center differentiation. 
A few days later, the patient developed fecaloid peritonitis due to cecal perforation. An unresectable tumour was found during laparotomy, so the surgeons sutured and drained the perforation and performed an ileostomy. The patient was referred to the Haematology Department, and was diagnosed with DLBCL relapse with gastrointestinal involvement after 37 years of disease-free survival. The haematologists investigated the stage of the disease, prescribed a prophase with methylprednisolone and treatment with R-GEMOX.

DLBCL represents $30 \%-58 \%$ of non-Hodgkin's lymphoma series (1). The extranodal involvement (as in our patient, in whom the gastrointestinal tract is involved) constitutes a risk factor in the International Prognostic Index (2). Gastrointestinal lymphomas are rare, and only 1-3\% are found in the colon. Patients typically present with abdominal pain, chronic diarrhea, abdominal mass, intestinal obstruction or perforation (3). The endoscopic appearance of the lesion may be nodular, ulcerated, infiltrative or a tumor macroscopically indistinguishable from an adenocarcinoma (4). In conclusion, we should be aware of the broad differential diagnosis of anemia, especially in patients with personal history of cancer.

\section{REFERENCES}

(1) Tilly $H$, Gomes da Silva $M$, Vitolo $U$ et al. Diffuse large B-cell lymphoma (DLBCL): ESMO Clinical Practice Guidelines for diagnosis, treatment and follow-up. Annals of Oncology 2015; 26: 116-125.

(2) Caimi P, Hill B, Hsi E et al. Clinical approach to diffuse large B cell lymphoma. Bloodreviews 2016; 30: 477-491.

(3) Mesonero Gismero F, Jiménez Martín A. Linfoma gástrico e intestinal. En: Gomollón F. Tratamiento de las enfermedades gastroenterológicas. 4aㅡ ed. Madrid: Asociación Española de Gastroenterología; 2020. p. 273-278.

(4) Muñoz González R, Miranda García P, Santander C. Linfoma no Hodgkin folicular con afectación primaria cólica. RevEspEnfermDig 2020;112(12):956-957. 


\section{FIGURE}
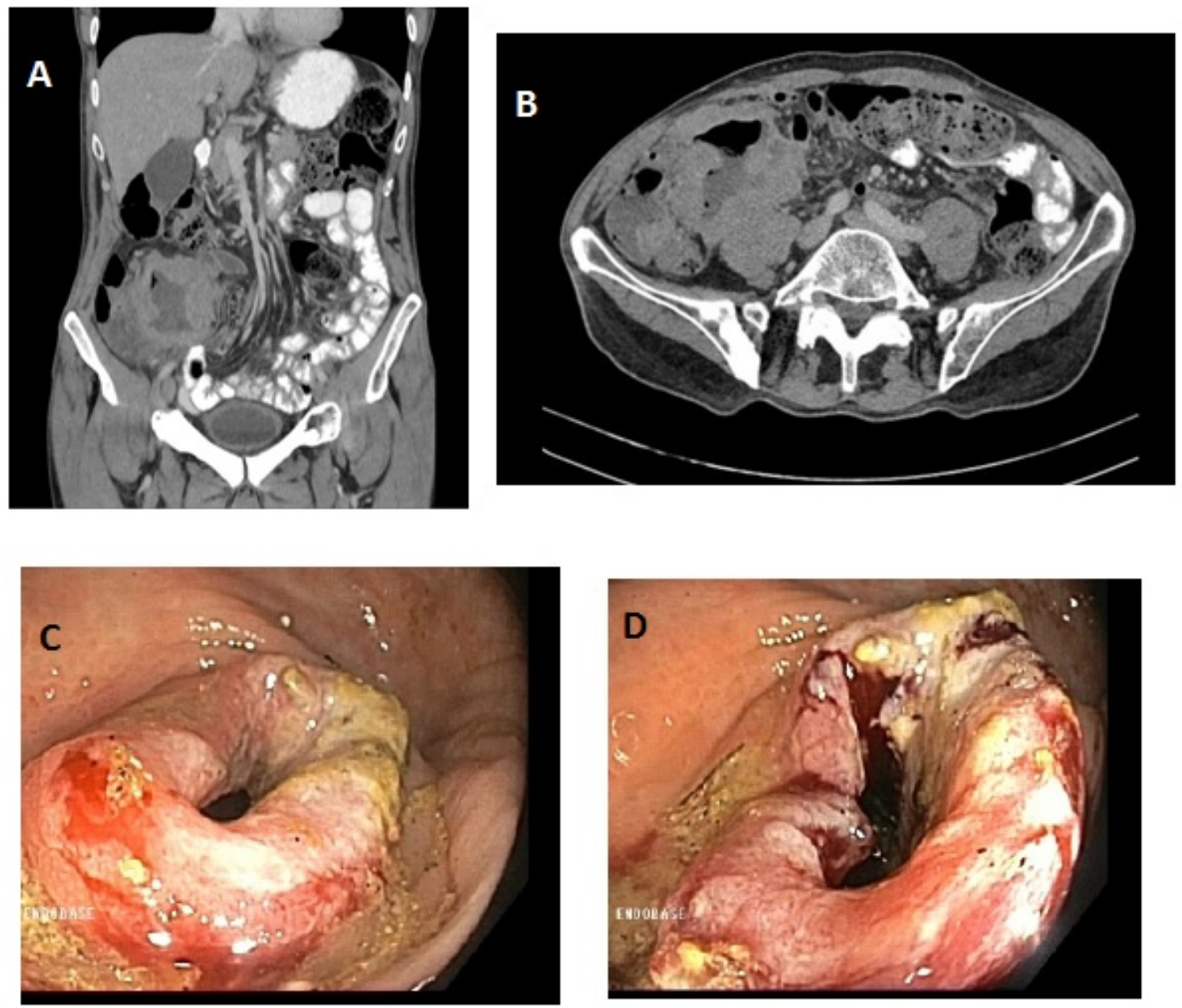

A. Figure 1. CT scan. Circumferential thickening of the wall of terminal ileum, with aneurysmal dilatation that gets to the ileocecal valve, with fat stranding and adenopathies surrounding the mass, suggestive of intestinal lymphoma. B. Coronal multiplanar reconstruction. C and D. Colonoscopy. In cecum, next to appendix, there is an infiltrative lesion with an orifice that seems to be fistulizated. 